\title{
YIELD RESPONSES OF WATERMELON (CITRULLUS LUNATUS (THUMB) IN A COASTAL PLAIN SOIL UNDER VARIABLE FERTILIZER RATES AND IRRIGATION REGIME IN A DRY SEASON PRODUCTION CYCLE
}

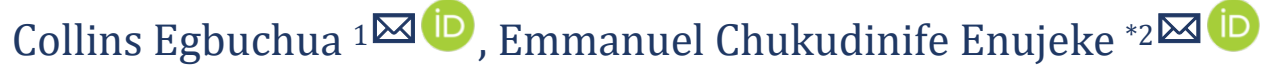 \\ 1, ${ }^{* 2}$ Department of Agronomy, Faculty of Agriculture, Delta State University, P.M.B. 95074, Asaba, \\ Nigeria
}

DOI: https://doi.org/10.29121/granthaalayah.v9.i3.2021.3794

\section{Article Type: Research Article}

Article Citation: Collins Egbuchua, and Emmanuel Chukudinife Enujeke. (2021). YIELD RESPONSES OF WATERMELON (CITRULLUS LUNATUS (THUMB) IN A COASTAL PLAIN SOIL UNDER VARIABLE FERTILIZER RATES AND IRRIGATION REGIME IN A DRY SEASON PRODUCTION CYCLE. International Journal of Research GRANTHAALAYAH, 9(3), 204-210. https://doi.org/10.29121/granthaa layah.v9.i3.2021.3794

Received Date: 04 March 2021

Accepted Date: 31 March 2021

Keywords:

Fertilizer Rates Irrigation Regime

Watermelon Yield

\section{ABSTRACT}

Field experiments were conducted during 2017 and 2018 cropping seasons at Illah, Delta North ecological zone of Nigeria to investigate the appropriate rates of NPK fertilizer and irrigation intervals in relation to yield response of water melon (Citrullus lunatus). The site had sandy loam texture, low in organic carbon $(0.38 \%)$, low in total nitrogen $(0.064 \%)$, available phosphorus (6.83 mgkg-1) and cation exchange capacity (6.74 cmolkg-1). The fertilizer rates were (0:0:0), (50:25:25), (80:40:40), and (120:60:60) KgN, P2O5 and K20/ha and irrigation regimes of 6:12:18 days. It was a factorial experiment laid out in a Randomized Complete Block Design with three replicates. Results indicated that increase in fertilizer rates from 0:0:0 to 80:40:40 kg/ha significantly increased growth and fruit yield. Further increase to $120: 60: 60 \mathrm{~kg} / \mathrm{ha}$ depressed yield. Increase irrigation intervals from $6-12$ days also influenced significantly growth and fruit yield and further increase to 18 days intervals affected negatively the parameters. Interaction effects between fertilizer $\mathrm{x}$ irrigation intervals were not significant. Correlation analysis showed that the growth and yield characters were significant and positively correlated with fruit yield. Results indicated that fertilizer rates and 12 days irrigation interval were adequate and recommended for increased production of watermelon in the study area.

\section{INTRODUCTION}

Watermelon (Citrullus lunatus var. Lunatus (Thumb) is a tropical fruit that belongs to the family cucurbitaceae and consists of nearly 100 genera and over 750 species (Enujeke;2014; Toth et al., 2007). The crop is believed to originate in the deserts of Kalahari in South Africa from where it got spread to other parts of the world including Nigeria (Shagufta, 2011). The rinds of watermelon are characteristically light green or pale green in colour and the fruit is relished for its delicate flavour and thirst quenching properties (Kim, 2008). Watermelon has been nutritionally and medically evaluated to be a very rich source of carotenoids which was said to have antioxidant activity due to free radical scavenging property (Arora et al., 2011; Kim, 2008). It is also known to be very rich in lycopene, a known antioxidant that gives the crop its characteristics colour. The fruit crop is considered to be free of fat, and contains about 92\% water and 8\% sugar (Mangila et al. 2007). The seeds have been identified to be a source

(c) 2021 The Author(s). This is an open access article distributed under the terms of the Creative Commons Attribution License, which permits unrestricted use, distribution, and reproduction in any medium, provided the original author and source are credited. 
of protein which is about $35 \%$ rich in protein. $50 \%$ oil and $5 \%$ dietary fibre and also rich in macro and micronutrients of magnesium, calcium, potassium, iron, phosphorus and zinc (Kim, 2008). It grows favourably in alluvial soils and does not require excessive soil moisture (Ndubizu, 2008, Aquaah, 2006). Thus, in Nigeria the largest production of the crop is the drier northern parts of the country where it is usually cultivated at the onset of the rains and towards the end of the rains in the much humid southern part of the country (De Lannoy, 2011; Toth et al., 2007).

In the tropics, watermelon grows and matures within 75-80 days of planting from seed to mature fruit and the aggressive vines can attain up to $50-60 \mathrm{~cm}$ in length in a well spaced environment. It also needs approximately 3 months of steady hot sunny weather to grow and ripen (IITA, 2013). Before this time in Nigeria, watermelon was generally perceived to grow and do very in the drier parts of the country with less moisture concentration. Recent trials by Oluloye et al. (2015). Nduka and Ike (2017) in the rainforest zone of Nigeria showed that the crop can thrive well in the environment but the production will be well-timed towards the end of rainy season with guided fertilizer application and efficient irrigation intervals to sustain moisture requirement. In Nigeria, the people are becoming aware of the importance of irrigated agriculture in boasting farmers income and reduction in dry season redundancy (Ndubizu, 2008). A good fertilizer use and irrigation intervals in crop production during the drier periods would enhance yield, improve crop quality and provide better soil moisture environment for crop yield (IITA, 2013). Because of the increasing involvement of youths in watermelon cultivation in order to make money and the increasing demand of the crop due to its nutritional values and the need to expand the growth of watermelon, the study therefore aimed at finding an appropriate levels of NPK fertilizer and irrigation frequency that will ensure good growth, development and fruit yield of watermelon in the coastal plain soil of Delta State, Nigeria.

\section{MATERIALS AND METHODS}

Field experiment were carried out in the 2017 and 2018 cropping seasons in a coastal plain soil in Illah. The vegetation is of humid rainforest with rainfall distribution of 1,850 - 2,550 mm/annum (NIMET, 2018). The topography is low-levelled and undulating and the soil is acid coastal plain soil. It is low is organic carbon (0.83\%), low in total nitrogen $(0.068 \%)$ low in phosphorus $\left(6.83 \mathrm{mgkg}^{-1}\right)$ and cation exchange capacity $\left(6.74 \mathrm{cmolkg}^{-1}\right) \mathrm{Table}$ 1. The temperature varied from $32.6^{\circ} \mathrm{C}$ to $34.3^{\circ} \mathrm{C}$ and a relative humidity of $75-82 \%$ (NIMET, 2018).

Field study: A piece of land measuring $50 \times 60 \mathrm{~m}^{2}$ was mapped out into basins of $2 \times 60 \mathrm{~m}^{2}$ each. Soil samples were randomly collected from the basins for the basins for the analysis of the initial physico-chemical properties of the soils. Watermelon variety "sugar baby" was sown in rows per basin with a sowing depth of $20 \mathrm{~cm}$ at $25 \mathrm{~cm}$ row sowing at seed rate of $100 \mathrm{~kg} / \mathrm{ha}$. Planting was done by drilling and later thinned to 3 seedlings per basin 2 weeks after sowing. The basins were uniformly irrigated a day after sowing via a flowing stream through irrigation canal. The experiment was a factorial experiment laid out in a randomized complete block design (RCBD). The treatments were NPK fertilizer rates of 0:0:0, 50:25:25, 80:40:40 and 120:60:60 kgN, $\mathrm{P}_{2} \mathrm{O}_{5}$ and $\mathrm{K}_{2} \mathrm{O}$ and irrigation intervals of 6; 12 and 18 days intervals were replicated 3 -times.

Fertilizer was applied according to rates in two (2) split doses at 2 and 6 weeks (WAP) by ring method $5 \mathrm{~cm}$ away from the crop. Irrigation treatments were done at 6,12 and 18 day interval. Weeding was done as at when necessary and insect pests were controlled using an insecticide called KARETE at $100 \mathrm{mls} / 20$ litres of water. The crop was harvested at full maturity at about 80 days after planting.

Data collected were vine-length, number of branches per plant, days to $50 \%$ anthesis, number of fruits per plant weight of fruits per plant and total fruit yield.

Statistical analysis: Data collected were subjected to analysis of variance (ANOVA). Differences between means were separated using Duncan Multiple Range Test (DMRT). Main effects of the treatment interactions were determined for all the parameters evaluated. Correlations coefficient was worked out to determine the relationship between growth, yield characters and total fruit yield of the crop. 
Yield Responses of Watermelon (Citrullus Lunatus (Thumb) in A Coastal Plain Soil Under Variable Fertilizer Rates and Irrigation Regime in A Dry Season Production Cycle

\section{RESULTS AND DISCUSSION}

\subsection{SOME PHYSICAL AND CHEMICAL PROPERTIES OF THE SOIL USED IN THE STUDY}

The initial soil physico-chemical properties of the experimental site (Table 1) showed that the soil was sandy clay loam in texture with $71.52 \%$ sand and $20.48 \%$ clay. The pH value of 5.18 indicated strongly acidic soil condition. The experimental site was low in organic carbon (0.38\%), total nitrogen $(0.064 \%)$, available phosphorus $(6.83 \mathrm{mgkg}$ 1) and cation exchange capacity $\left(6.74 \mathrm{cmolkg}^{-1}\right)$. The results of the initial physico-chemical properties are in consonance with reports of NIMET (2018) which indicated the meteorological data for the region.

Table 1: Some physical and chemical Properties of the soil used in the study

\begin{tabular}{|c|c|}
\hline Variables & Value Obtained \\
\hline Soil pH $\left(\mathrm{H}_{2} \mathrm{O}\right)$ & 5.18 \\
\hline Organic carbon (\%) & 0.38 \\
\hline Total nitrogen (\%) & 0.06 \\
\hline Available phosphorus (mgkg-1) & 6.83 \\
\hline Exchangeable Ca $\left(\mathrm{cmolkg}^{-1}\right)$ & 2.20 \\
\hline Exchangeable $\mathrm{Mg}\left(\mathrm{cmolkg}^{-1}\right)$ & 2.08 \\
\hline Exchangeable $\mathrm{K}\left(\mathrm{cmolkg}^{-1}\right)$ & 0.04 \\
\hline CEC $\left(\mathrm{cmolkg}^{-1}\right)$ & 6.74 \\
\hline Particle Size distribution $(\%)$ & \\
\hline Sand & 71.52 \\
\hline Silt & 8.00 \\
\hline Clay & 20.48 \\
\hline Textural class & Sandy clay loam \\
\hline
\end{tabular}

\subsection{EFFECTS OF NPK FERTILIZER RATES AND IRRIGATION INTERVALS ON THE LENGTH OF VINE AND NUMBER OF BRANCHES/PLANT OF WATER-MELON (CITRULLUS LUNATUS)}

The effect of NPK fertilizer and irrigation rates on vine-length and number of branches per plant is shown in Table 2. Increase in rates of NPK fertilizer from 0:0:0 to 50:25:25 KgN, $\mathrm{P}_{2} \mathrm{O}_{5}$ and $\mathrm{K}_{2} \mathrm{O}$ significantly increased vine length from $516.3 \mathrm{~cm}$ to $608.2 \mathrm{~cm}$ and $514.3 \mathrm{~cm}$ to $610.2 \mathrm{~cm}$ in the corresponding 2018 seasons. The same increase in the number of branches per plant was observed in the corresponding season. Further increase to 80:40:40 also increase vine length to $728.2 \mathrm{~cm}$ in 2017 season and 750.2 in 2018 . The same trend was observed on the number of branches per plant in this manner 32.0 to 35.3 but reduced significantly to 28.2 and 32.3 in 2018 season. Further increase in application rates to 120:60:60 significantly reduced vine length to $520.3 \mathrm{~cm}$ and 530.4 in the 2017 and 2018 seasons. Number of branches per plant was also statistically similar even when there was a reduction in the number of branches per plant in the years of cropping (Table 2). Similar observations were made by NIHORT (2008), Mani et al (2006) who reported that fertilizer rates affected growth and yield parameters of crops.

Table 2: Effects of NPK Fertilizer rates and irrigation intervals on the length of vine and number of branches/plant of water-melon (Citrullus lunatus)

\begin{tabular}{|c|c|c|c|c|}
\hline Treatment & \multicolumn{2}{|c|}{ Length of Vine (cm) } & \multicolumn{2}{c|}{ Number of branches/plant } \\
\hline & 2017 & 2018 & 2017 & 2018 \\
\hline NPK Fertilizer $(\mathrm{Kg} / \mathrm{ha})$ \\
\hline $0: 0: 0$ & $516.3^{\mathrm{b}}$ & $514.3^{\mathrm{b}}$ & $24.2^{\mathrm{c}}$ & $22.3^{\mathrm{b}}$ \\
\hline $50: 25: 25$ & $608.2^{\mathrm{ab}}$ & $610.2^{\mathrm{ab}}$ & $32.0^{\mathrm{ab}}$ & $28.2^{\mathrm{b}}$ \\
\hline $80: 40: 40$ & $728.2^{\mathrm{a}}$ & $750.2^{\mathrm{a}}$ & $35.3^{\mathrm{a}}$ & $32.3^{\mathrm{a}}$ \\
\hline $120: 60: 60$ & $520.3^{\mathrm{b}}$ & $530.4^{\mathrm{b}}$ & $21.6^{\mathrm{b}}$ & $17.4^{\mathrm{c}}$ \\
\hline SE \pm & 50.4 & 49.4 & $4^{*}$ & $* *$ \\
\hline
\end{tabular}


Collins Egbuchua, and Emmanuel Chukudinife Enujeke

\begin{tabular}{|}
\begin{tabular}{|c|c|c|c|c|}
\hline \multicolumn{5}{|l|}{ Irrigation Intervals } \\
\hline 6 & $534.2^{\mathrm{b}}$ & $514^{\mathrm{b}}$ & $24.6^{\mathrm{b}}$ & $21.3^{\mathrm{a}}$ \\
\hline 12 & $741.2^{\mathrm{a}}$ & $710.4^{\mathrm{a}}$ & $36.0^{\mathrm{a}}$ & $21.3^{\mathrm{a}}$ \\
\hline 18 & $502.2^{\mathrm{b}}$ & $492.2^{\mathrm{b}}$ & $21.0^{\mathrm{c}}$ & $18.4^{\mathrm{b}}$ \\
\hline $\mathrm{SE} \pm$ & 46.4 & 42.2 & 2.25 & 2.08 \\
\hline Interaction \\
\hline $\mathrm{NPK} \times$ II & $\mathrm{NS}$ & $\mathrm{NS}$ & $\mathrm{NS}$ & $\mathrm{NS}$ \\
\hline $\mathrm{NPK} \times \mathrm{I}$ & & & & \\
\hline
\end{tabular}
\end{tabular}

Means with the same letter(s) under same column are not significantly different at $5 \%$ level of probability using Duncan Multiple Range Test (DMRT).

NS $=$ Not significant.

\subsection{EFFECTS OF NPK FERTILIZER RATES AND IRRIGATION INTERVALS ON DAYS TO 50\% ANTHESIS AND NUMBER OF FRUITS PER PLANT OF WATER-MELON (CITRULLUS LUNATUS)}

Effects on days to $50 \%$ anthesis and number of fruits per plant (Table 3) showed that there were statistically similar and no much effect on treatment rates from the control. Even when the rates were increased from 0:0:0 to 120:60:60 KgN, $\mathrm{P}_{2} \mathrm{O}$ and $\mathrm{K}_{2} \mathrm{O}$. there was no statistical difference. The same trend was observed in the 2018 seasons. Number of fruits were significantly influenced by rates as application rates of 0:0:0 to 50:25:25 $\mathrm{KgN}_{2} \mathrm{P}_{2} \mathrm{O}_{5}$ and $\mathrm{K}_{2} \mathrm{O}$ reduced the number of fruits per plant to the value of 0:0:0 kgN, $\mathrm{P}_{2} \mathrm{O}_{5}$ and $\mathrm{K}_{2} \mathrm{O}$ of 4.0 and 3.5 respectively (Table 3). This is not different from the findings of Nduka and Ike (2017) who reported that certain rates of fertilizer could enhance growth and yield of crops, but could depress yield at very high levels of application.

Table 3: Effects of NPK Fertilizer rates and irrigation intervals on days to $50 \%$ anthesis and number of fruits per plant of water-melon (Citrullus lunatus)

\begin{tabular}{|c|c|c|c|c|c|c|}
\hline Treatment & \multicolumn{3}{|c|}{ Days to $50 \%$ anthesis } & \multicolumn{3}{c|}{ No of fruits/Plants } \\
\hline & 2017 & 2018 & $\overline{\mathrm{X}}$ & 2017 & 2018 & $\overline{\mathrm{X}}$ \\
\hline NPK Fertilizer rates $(\mathrm{Kg} / \mathrm{ha})$ \\
\hline 0 & $40.0^{\mathrm{b}}$ & $42.0^{\mathrm{b}}$ & $41.0^{\mathrm{b}}$ & 3.0 & $4.0^{\mathrm{b}}$ & $3.5^{\mathrm{b}}$ \\
\hline 30 & $42.0^{\mathrm{b}}$ & $43.0^{\mathrm{a}}$ & $42.5^{\mathrm{b}}$ & $4.0^{\mathrm{b}}$ & $6.0^{\mathrm{b}}$ & $5.0^{\mathrm{b}}$ \\
\hline 60 & $43.0^{\mathrm{a}}$ & $45.0^{\mathrm{a}}$ & $44.0^{\mathrm{a}}$ & $7.0^{\mathrm{a}}$ & $9.0^{\mathrm{a}}$ & $8.0^{\mathrm{a}}$ \\
\hline 90 & $40.0^{\mathrm{b}}$ & $41.5^{\mathrm{b}}$ & $40.8^{\mathrm{b}}$ & $3.0^{\mathrm{b}}$ & $4.0^{\mathrm{b}}$ & $3.5^{\mathrm{b}}$ \\
\hline SE \pm & 0.38 & 0.40 & 0.36 & $0.5^{\circ}$ & 0.61 & 0.59 \\
\hline Irrigation interval \\
\hline 6 & $42.8^{\mathrm{a}}$ & $43.6^{\mathrm{a}}$ & $43.2^{\mathrm{b}}$ & $3.6^{\mathrm{b}}$ & $4.8^{\mathrm{b}}$ & $4.2^{\mathrm{b}}$ \\
\hline 12 & $42.5^{\mathrm{a}}$ & $49.9^{\mathrm{a}}$ & $46.2^{\mathrm{a}}$ & $3.9^{\mathrm{a}}$ & $5.5^{\mathrm{a}}$ & $4.7^{\mathrm{a}}$ \\
\hline 18 & $4.0^{\mathrm{b}}$ & $40.5^{\mathrm{c}}$ & $40.8^{\mathrm{b}}$ & $1.7^{\mathrm{c}}$ & $3.2^{\mathrm{c}}$ & $2.5^{\mathrm{c}}$ \\
\hline SE \pm & $* *$ & 0.35 & 0.36 & $* *$ & $* *$ & $* *$ \\
\hline Interaction \\
\hline NPK x I & NS & NS & NS & NS & NS & NS \\
\hline
\end{tabular}

Means followed by the same letter(s) within the treatment groups are not significantly different at $5 \%$ level of probability using DMRT.

NS = Not significant

$\mathrm{xx} .=$ highly significant

\subsection{EFFECTS OF NPK FERTILIZER RATES AND IRRIGATION INTERVALS ON WEIGHT OF FRUIT YIELD INDICES OF WATER-MELON (CITRULLUS LUNATUS)}

On the effect of treatment on weight of fruits (Table 5), the same trend was observed as further increase in rates to $120: 60: 60 \mathrm{KgN}, \mathrm{P}_{2} \mathrm{O}_{5}$ and $\mathrm{K}_{2} \mathrm{O}$ simultaneously decrease the yield characters evaluated. Similar results were reported by Ibrahim et al. (2011), Aquaah(2006 and Swain et al.(2006) 
Increase in irrigation intervals from 6 -12 days interval significantly increased vine length, from $534.2 \mathrm{~cm}$ to $744.2 \mathrm{~cm}$ in the 2017 season and $514.2 \mathrm{~cm}$ to $710.4 \mathrm{~cm}$ in 2018 season but further increase in irrigation regime to 18 days interval had reduction effect on the parameters evaluated. Number of branches per plant also depressed with further increase in irrigation intervals to 18 days interval in the corresponding years. The same trend was observed on the number of fruits per plant, weight of fruits per plant and total fruit yield. However further increase to 18 days interval significantly decreased the growth and yield characters investigated (Table 2). On days to $50 \%$ anthesis and number of fruits per plant (Table 3) the same trend of statistical similarity was observed. Further increase to 18 days irrigation interval relatively reduced days to $50 \%$ anthesis in both seasons. The same trend was observed on the number of fruits per plant, weight of fruits per plant and total yield of fruits (Tables 3, 4 and 5).

Table 4: Effects of NPK fertilizer rates and irrigation intervals on weight of fruits/ plant of water-melon (Citrullus lunatus)

\begin{tabular}{|c|c|c|c|}
\hline Treatment & \multicolumn{3}{|c|}{ Weigh of fruit/plant (g) } \\
\hline & 2017 & 2018 & $\overline{\mathrm{X}}$ \\
\hline \multicolumn{4}{|c|}{ NPK fertilizer $(\mathrm{Kg} / \mathrm{ha})$} \\
\hline 0 & $9.0^{b}$ & $9.6^{b}$ & $9.3^{b}$ \\
\hline 30 & $13.0^{\mathrm{ab}}$ & $15.4^{\mathrm{ab}}$ & $14.2^{\mathrm{a}}$ \\
\hline 60 & $16.0^{\mathrm{a}}$ & $17.2^{\mathrm{a}}$ & $16.6^{\mathrm{a}}$ \\
\hline 90 & $7.0^{c}$ & $9.0^{c}$ & $8.0^{c}$ \\
\hline SE \pm & 1.20 & 1.38 & 1.32 \\
\hline \multicolumn{4}{|c|}{ Irrigation Interval } \\
\hline 6 & $9.0^{\mathrm{b}}$ & $11.0^{\mathrm{b}}$ & $10.0^{b}$ \\
\hline 12 & $16.6^{a}$ & $18.8^{\mathrm{a}}$ & $17.7 \mathrm{a}$ \\
\hline 18 & $8.10^{b}$ & $9.65^{c}$ & $1.01^{\mathrm{c}}$ \\
\hline SE \pm & 0.85 & 1.02 & 0.12 \\
\hline \multicolumn{4}{|l|}{ Interaction } \\
\hline NPK x I & NS & NS & NS \\
\hline
\end{tabular}

Means with the same letter(s) under same column are not significantly different at $5 \%$ level of probability using Duncan Multiple Range Test (DMRT).

NS = Not significant.

Table 5: Effects of NPK fertilizer rates and irrigation intervals on total fruit yield (t/ha) of water-melon (Citrullus lunatus)

\begin{tabular}{|c|c|c|c|}
\hline Treatment & \multicolumn{3}{|c|}{ Weigh of fruit/plant (g) } \\
\hline & 2017 & 2018 & $\overline{\mathrm{X}}$ \\
\hline \multicolumn{4}{|c|}{ NPK fertilizer (Kg/ha) } \\
\hline 0 & $6.44^{b}$ & $5.60^{c}$ & $6.02^{c}$ \\
\hline 30 & $8.68^{\mathrm{ab}}$ & $6.65^{\mathrm{ab}}$ & $7.66^{\mathrm{b}}$ \\
\hline 60 & $12.9^{a}$ & $10.24^{\mathrm{a}}$ & $11.57 \mathrm{a}$ \\
\hline 90 & $4.50^{\mathrm{c}}$ & $6.08^{c}$ & $5.29^{c}$ \\
\hline SE \pm & 0.21 & 0.26 & 0.19 \\
\hline \multicolumn{4}{|c|}{ Irrigation Interval } \\
\hline 6 & $7.52^{b}$ & $4.44 \mathrm{c}$ & $8.46^{b}$ \\
\hline 12 & $14.50^{\mathrm{a}}$ & $16.59^{a}$ & $15.50^{\mathrm{a}}$ \\
\hline 18 & $6.08^{b}$ & $7.12^{\mathrm{b}}$ & $6.6^{b}$ \\
\hline $\mathrm{SE} \pm$ & 0.64 & 0.72 & 0.70 \\
\hline \multicolumn{4}{|l|}{ Interaction } \\
\hline NPK x 1 & NS & NS & NS \\
\hline
\end{tabular}

Means followed by the same letter(s) within the treatment groups are not significantly different at $5 \%$ level of probability using DMRT.

NS = Not significant 


\subsection{INTERACTION EFFECTS OF NPK FERTILIZER AND IRRIGATION INTERVALS}

The interaction effects of NPK fertilizer and irrigation intervals were not significant, and application rates of 80:40:40 KgN, $\mathrm{P}_{2} \mathrm{O}_{5}$ and $\mathrm{K}_{2} \mathrm{O}$ produced the highest numbers of growth characters investigated and fruit yield in both seasons evaluated. The relationship that existed between total yield and growth components of watermelon indicated a positive and significant correlation with vine-length (0.768), number of branches per plant (0.584), weight of fruit per plant (0.645) number of fruits per plant (0.345) were significantly correlated with fruit yield. Days to $50 \%$ anthesis $(-0.541)$ was highly significant but negatively correlated with fruit yield. The high significant correlation between growth and yield characters evaluated implied that they all contributed greatly either directly or indirectly in promoting good growth and fruit yield of watermelon in the study location.

\section{CONCLUSION AND RECOMMENDATION}

In conclusion, a good fertilizer rate and irrigation interval are complimentary in advancing dry season crop production in the southern part of Nigeria.

The present study showed that the use of NPK fertilizer rates of 80:40:40 KgN, $\mathrm{P}_{2} \mathrm{O}_{5}$ and $\mathrm{K}_{2} \mathrm{O}$ and 12 days irrigation interval favourably influenced growth and yield parameters of watermelon, hence the fertilizer rate and irrigation regime are recommended for increased production of the crop.

\section{SOURCES OF FUNDING}

This research received no specific grant from any funding agency in the public, commercial, or not-for-profit sectors.

\section{CONFLICT OF INTEREST}

The author have declared that no competing interests exist.

\section{ACKNOWLEDGMENT}

The authors wish to acknowledge the assistance provided by Illah youths in land preparation, planting and watering in the course of the research, and some technical and statistical inputs from both academic and technical staff of the Department.

\section{REFERENCES}

[1] Acquaah, G. Principles of crop production: Theory, techniques and technology. Prentice-Hall of India Publishers New Delhi, India, 2006.

[2] Arora, R., Kauv, M. and Gill , N.S. Antioxidant Activity and Pharmacological Evaluation of Cucumis melo var. agrestia methanolic seed extract. Res. J. Phytochemistry 5, 2011, 146-155

[3] Awe, O.A., Abdulsam, R.A. and Ogunsola. Effect of NPK 20-10-10 fertilizer on the pod yield and root growth of okra in the humid tropics. Proc. Ann. Conf. Soil Sci. Soc. Nigeria, 13-17 Nov. 2006 Ahmadu Bello University Zaria, Nigeria, 2006.

[4] DeLannoy. Crop production in tropical Africa Romain, H.R. (ed) published by Director General for International Cooperation (DGIC) Brussets, Belgium. 2011. 236-238

[5] Enujeke, E.C. An Assessment of Some Growth and Yield Indices of Six Varieties of Watermelon (Citrulus Lanatus Thumb) in Asaba Area of Delta State, Nigeria. Trop. Agric. Res. \& Ext. 16(4), 2014, 122-129

[6] Gudugi, I.A.S., Odofin, A.J., Adeboye, M.K.A and Oladiran, J.A.. Effect of irrigation interval and mulching on growth and yield of tomato in South Guinea Savanna, Nigeria. Proc. Ann. Conf. Soil Sci. Soc. Nigeria 7-11 March. 2011, Fed. Univ. of Tech., Minna. 
Yield Responses of Watermelon (Citrullus Lunatus (Thumb) in A Coastal Plain Soil Under Variable Fertilizer Rates and Irrigation Regime in A Dry Season Production Cycle

[7] Ibrahim, H,, Gudigi, A.S., Oladiran, .J. A., Odofin, A.J.., Adeboye, M.K.A. and Oyentunde, G.O. The effect of mollerplant irrigation schedule on the quality of tomato (Lycopersicum esculentum) seed. Proc. Ann. Conf. Soil Sci. Soc. Nigeria 7-11 March. 2011, Fed.Univ. Tech., Minna.

[8] IITA. Growing watermelon commercially in Nigeria-an illustrated guide. International Institute of Tropical Agriculture (IITA), 2013, 1-16

[9] Kim, B. 2008. Watermelon nutrition: How to get the most nutritional value out of watermelon. Health and Beyond http://www.chetday.com/index-html retrieved

[10] Mangila, E. Tabiliran, F.P., Naguit, M.R.A. and Malate, R.. Effects of organic fertilizer on the yield of watermelon Threshold 2. January-December. 2007, .27-35

[11] Ndubizu. 2008. Advances in fruit farming in Nigeria. International Society of Horticultural Science. http://www.ishs.org/1662010

[12] Nduka, P.C. and Ike, O.O. Watermelon and Related Crop Species Production under Different Soil Conditions as Influenced by Variable Fertilizer and Water Management Regime. Crop Res. 3(2), 2017, 31-42

[13] NIHORT - Nigeria Institute of Horticultural Crop Research. Res. Bulletin 12(6), 2008, 8-121.

[14] NIMET - Nigerian Meteorological Institute. Information on climatic data in Asaba and Environs, Delta State, Nigeria (In-House Print Bi-monthly Publication, 2018.

[15] Oluloye, R.C., Kunle, P.O. and Ogundipe, C.O. Performance of watermelon (Cittrullus lunatus) in a dry season condition under controlled irrigation scheduler. In: Irrigation and sustainable agriculture conference, Ibadan, Nigeria. 2015, 74-83

[16] Scholten, M., Dohahue, J. Shaw, N.L. and Serpe, M.D. Environmental regulation of dormancy loss in seeds of Lomatium dissectum. Annl. of Bot. 103(7), 2009, 1091-1101

[17] Shagufta, C.J. Vegetable and crop production. APH Publishing Corporation, Darya Ganj, New Delhi, India. 2011, 183-259

[18] Swain, A.J., Hughes, Z.S., Cook, S,,K and Moses, R. Quantifying the dormancy of Alopecurus myosuroides seeds produced by plants exposed to different soil moisture and temperature regimes. Weed Res. 46(6), 2006, 470479

[19] Ufoegbenene, G.C., Fadipe, A.O., Bellow, N.J., Eruola, O.A., Makinde, A.A. and Amori, A.A. Growth and development of watermelon in response to seasonal variation of rainfall. J. Climatology \& Weather Forecasting 2(2), 2014, 1-6

[20] Wikipedia encyclopaedia. Growth and yield performance of watermelon www.wikipedia.com/productionguideofwatermelon.da.gov.ph2010. http://www.da.gov.ph/2010. 